\begin{tabular}{|l|l|c|}
\hline $\begin{array}{l}\text { 2. To: (Receiving Organization) } \\
\text { SST Retrieval Engineering }\end{array}$ & $\begin{array}{l}\text { 3. From: (Originating Organization) } \\
\text { SST Retrieval Engineering }\end{array}$ & $\begin{array}{c}\text { 4. Related EDT No.: } \\
610559\end{array}$ \\
\hline $\begin{array}{l}\text { 5. Proj./Prog./Dept./Div.: } \\
\text { W-320 }\end{array}$ & $\begin{array}{l}\text { 6. Design Authority/ Design Agent/Cog. } \\
\text { Engr: : }\end{array}$ & 7. Purchase Order No.: \\
\hline
\end{tabular}

8. Originator Remarks:

Supporting Document Approval and Initial Release

9. Equip./Component No.:

AY \& C-Farm Electrical

10. System/Bldg./Facility: 241-C-106

11. Receiver Remarks: 11A. Design Basel ine Document? [X] Yes [] Wo

12. Major Assm. Dwg. No.:

$\mathrm{H}-2-820748$, sht $1 \& 2$, $\mathrm{H}-2-820751$, sht 1

13. Permit/Permit Application No.: N/A

14. Required Response Date: $N / A$

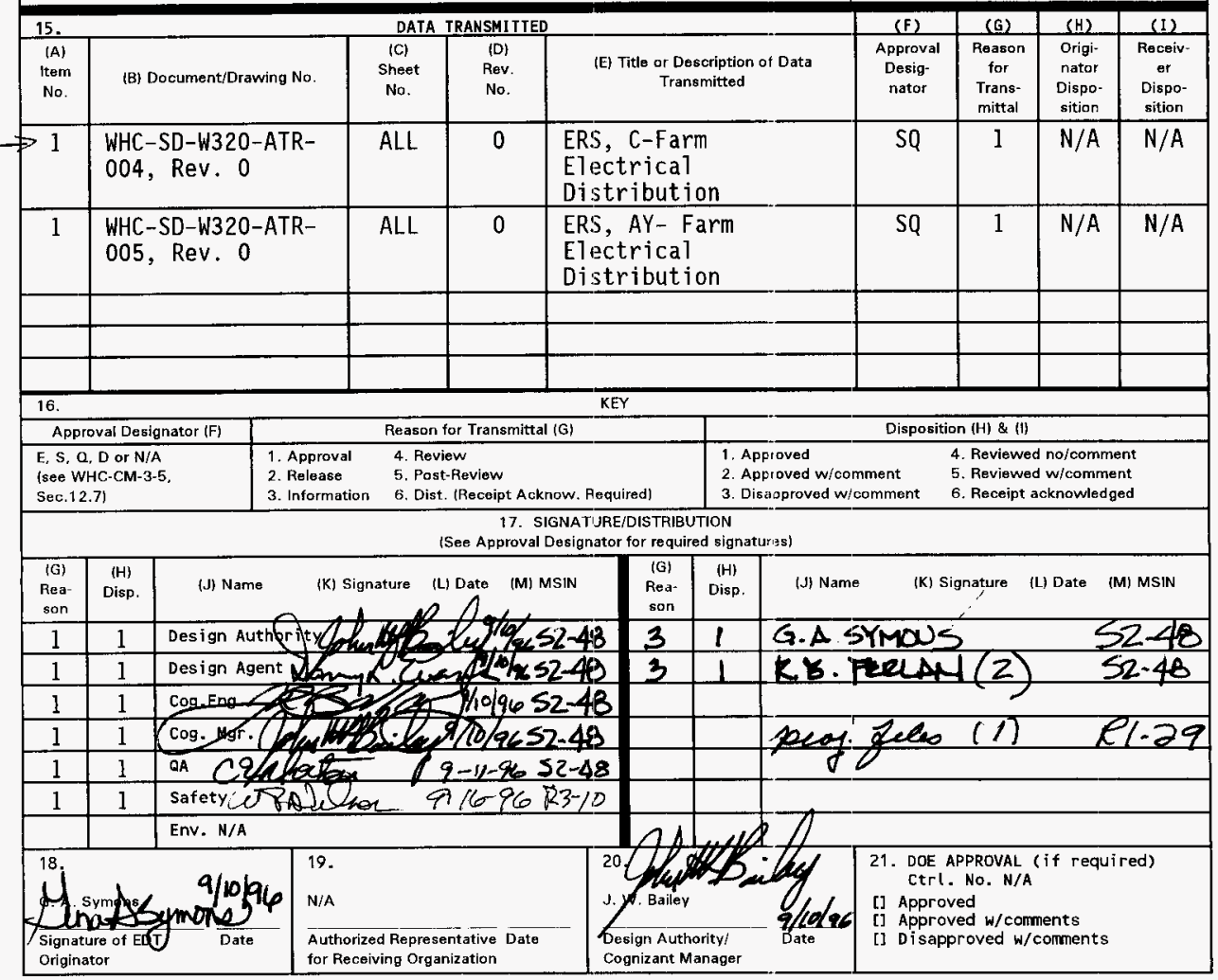




\section{ERS, C-Farm Electrical Distribution}

\section{G.A. Symons}

WHC, Richland, WA 99352

U.S. Department of Energy Contract DE-AC06-87RL10930
EDT/ECN: 610559
UC: 510
Org Code: 73530
Charge Code: D2MP6
B\&R Code: EW3130010
Total Pages: 22

Key Words: 24I-C-106, C-Farm Electrical Distribution, Equipment Removal System, Project $\mathrm{H}-320$

Abstract: Project W-320 Acceptance Test Report for ERS, C-Farm Electrical Distribution

TRADEMARK OISCLAIMER. Reference herein to any specific comercial product, process, or service by trade name, trademark, manufacturer, or otherwise, does not necessarily constitute or imply its endorsement, recommendation, or favoring by the United states Government or any agency thereof or its contractors or subcontractors.

Printed in the United States of America. To obtain copies of this document, contact: WHC/BCS Document Control Services, P.0. Box 1970, Mailstop H6-08, Richland WA 99352, Phone (509) 372-2420; Fax (509) 376-4989.
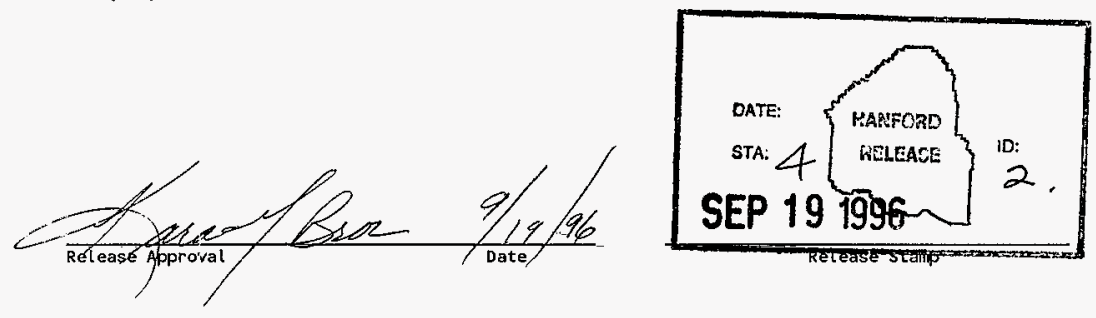

Approved for Public Release 
ACCEPTANCE TEST PRDCEDURE WHC-SD-H320-ATR-004

TEST TITLE ERS, C-Farm Electrical Distribution

LOCATION C-Farm

PROJECT NUMEER W-320 WORK ORDER ER6159

PROJECT TITLE W-320 Equioment Removal System

Prepared By

ICF Xaiser Hanford Company

Richland, Washington

For Westinghouse Hanford Company

Subcontract WHC-380393

PROCEDURE APPROVAL

ICF KAISER HANFORD COMPANY (ICF XH)

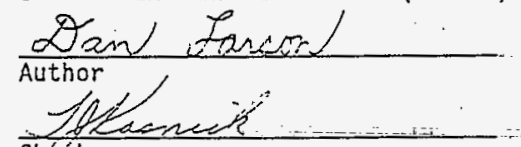

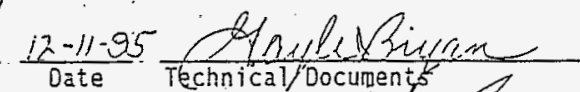
$\frac{12 / 11 / 95}{0 a t a}$

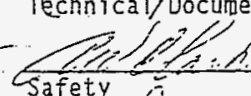

checker

Cteonelsa mit

Environmental

Prosect management

Date Safety

icit $\frac{1}{\mathrm{k} i \mathrm{i}}$

efing

$\frac{42 \cdot 7-45}{\text { Date }}$

$\frac{12-6+t=5}{\text { Date }}$

$\frac{12-11-95}{\text { Date }}$

Westinghouse Hanford Company (WHC)
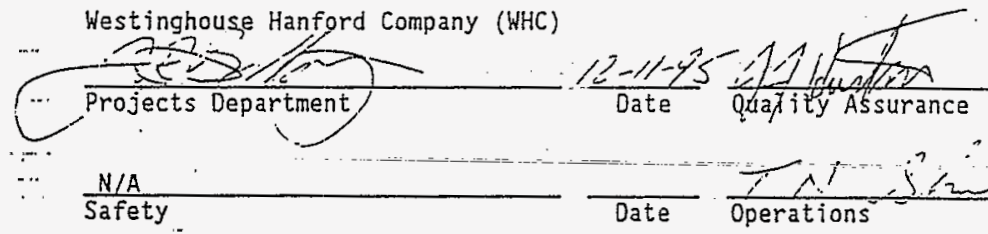

$\frac{12-11-62}{\text { Date }}$

$\frac{N / A}{\text { Safety }}$
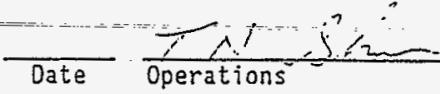

$\frac{12-11-3: 5}{\text { Date }}$ 


\section{EXECUTED BY}

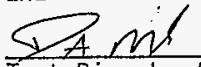

Test Director/Organization

Sori Wablori

Recorder/Organization

D.o. Wallace Fepkt

$\frac{1 / 5 / 96}{1 / 50}$

Date

\section{WITNESSES}

MQDereat

Witness/Organization

Tim trasnicky ICFKH

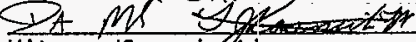

Witness/Organization

DAUE MORASCH

A-E APPROVAL

ICF Kaiser Hanford Company (ICF KH)

Without

exceptions $x$

G.5. Chruery

Ácceptance Inspection

Semulully Jamb Licer

Project Manager
With exceptions

resolved
1/5/96 D.0. Wablas

Date Tithe III Insgector Fefkt Date $1 / 5 / 96$ N/A

TEST APPROVAL AND ACCEPTANCE

Westinghouse Hanford Company

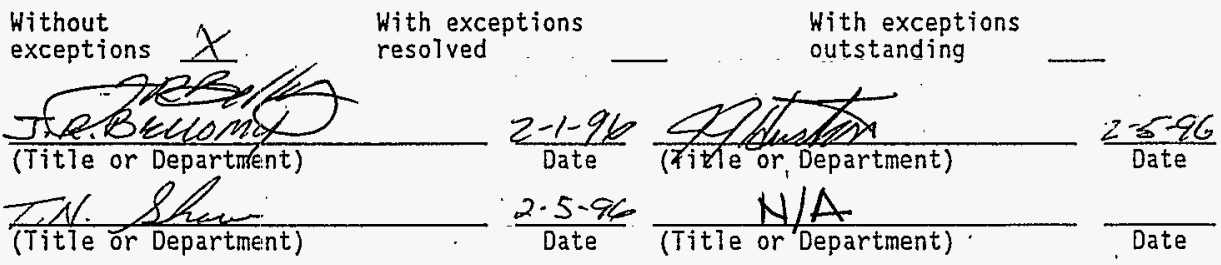

With exceptions

outstanding

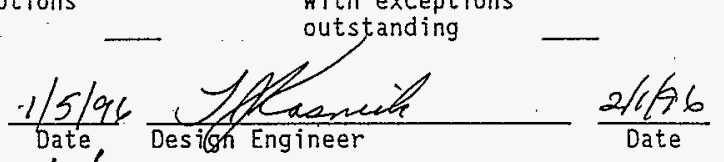

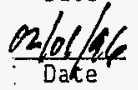

$5-26$

Date 
TITLE/PROCEDURE APPROVAL

EXECUTION AND TEST APPROVAL 2

TABLE OF CONTENTS

PURPOSE

4

REFERENCES.

RESPONSIBILITIES

$$
4
$$

3

4

CHANGE CONTROL

EXECUTION

6

EXCEPTIONS .

PREREQUISITES, EQUTPMENT/INSTRUMENTS, AND ABBREVIATIONS > 8

EQUIPMENT REMOVAL SYSTEM - C-FARM ELECTRICAL TESTS , 11

TEST COMPLETION FINAL EQUIPMENT LINEUP 18

DATA SHEET

EXCEPTION FORM 20

NOTE: At completion of test, enter pages added during performance of test to this Table of Contents. 
I. PURPOSE

This Acceptance Test Procedure (ATP) has been prepared to demonstrate that the C-Farm Electrical Distribution, in the Equipment Removal System portion of Project $W-32,0$, functions as required by the design criteria.

2

\section{REFERENCES}

2.1 DRAWINGS

$\mathrm{H}-2-820748$, Sh 1, Rev 0

$\mathrm{H}-2-820748$, Sh 2, Rev 0

2.2 SPECIFICATIONS

Construction Specification W-320-C2

2.3 ENGINEERING CHANGE NOTICES. (ECNS)

Prior to final test approval, markup the controlled copy of this ATP with all of the ECNS written against it.

3 RESPONSIBILITIES

3. 1 GENERAL

Each company or organization participating in this ATP will designate personnel to assume the responsibilities and duties as defined herein for their respective roles. The designees shall become famitiar with this ATP and the systems involved to the extent that they can perform their assigned duties.

3.2 WHC PROJECT ENGINEER

3.2.1 Designates a Test Director.

3.2.2 Signs Execution and Test Approval page when test is complete and accepted.

3.2.3 Signs exception form when att exceptions have been resolved.

3.2.4 Provides a distribution list for the approved and accepted ATP.

\subsection{TEST DIRECTOR}

3.3.1 Coordinates and directs acceptance testing.

3.3.2 Coordinates testing with ICF KH UtiTities.

3.3.3 Coordinates testing with ICF KH Craft.

3.3.4 Distributes the approved testing schedule before start of testing.

3.3.5 Notifies concerned parties when a change is made in the testing schedule. 
3.3.6 Schedules and conducts a pretest kickoff meeting with test participants when necessary.

3.3.7 Confirms that field testing and inspection of the system or portion of the system to be tested has been completed.

3.3.8 Stops any test which, in his or her judgement, may cause damage to the system untif the problem has been resolved.

3.3.9 After verifying there is no adverse impact, may alter the sequence in which systems or subsystems are tested.

3.3.10 If a test is to be suspended for a period of time, ensures that the system is left in a safe mode.

3.3.11 Before restarting suspended test, reverifies the test prerequisites.

3.3.12 Initiates ECNs to document required changes to the ATP.

3.3.13 Reviews recorded data, discrepancies, and exceptions.

3.3.14 Signs Execution and Test Approval page when test has been performed.

3.3.15 Takes necessary actions to clear exceptions to the test, and signs exception form when exceptions have been resolved.

3.3.16 Obtains required signatures on the ATP Master before reproduction and distribution.

3.4 WITNESSES (Provided by Participating Organizations. One witness shall be a Title III acceptance inspector.)

3.4.1 Witnesses the tests.

3.4.2 Reviews results of testing.

3.4.3 Assists the Test Director when requested.

3.4.4 Signs Execution and Test Approval page when test has been performed.

3.4.5 Signs exception form when exception has been resolved.

3.5 RECORDER (Provided by ICF KH)

3.5.1 Prepares a field copy from the ATP Master.

3.5.2 Records names of all designated personnel on field copy of ATP before start of testing.

3.5.3 Records test instrument identification numbers and catibration expiration dates, as required.

3.5.4 Initials and dates every test step on the field copy as it is completed next to the step number or on a Data Sheet, when provided. Records test data. 
3.5.5 Records exceptions on an exception form. Uses additional exception forms as needed. Notifies the Test Director at time the exception is made.

3.5.6 Signs Execution and Test Approval page when test has been performed.

3.5.7 After test is finished, assigns alpha numeric page numbers to added data sheets and exception forms. Records page numbers in the Table of Contents.

3.5.8 Transfers Field copy entries for each step to the Master in ink or type, signs, and dates. Transmits the completed Master to the Test Director for approval signature routing. Transmits the Field copy to Construction Document Control for inclusion in the official project file.

3.5.9 Signs exception form when exception has been resolved and transmits to Test Director.

3.6 TEST OPERATOR

3.6.1 Performs test under direction of the Test Director.

3.6.2 Provides labor, equipment, and test instruments required for performing tests which have not been designated as being provided by others.

3.6.3 Confirms that all equipment required for performing test will be available at the start of testing.

3.6.4 Signs the Execution and Test Approval page.

3.7 A-E ACCEPTANCE INSPECTION, DESIGN ENGINEER, AND PROJECT MANAGER

3.7.1 Evaluates results.

3.7.2 Signs for A-E Approval on Execution and Test Approval page.

4

CHANGE CONTROL

Required changes to this ATP must be processed on ECNs in accordance with company procedures. If a need for change is discovered in the course of running the test, the test shall be stopped until the ECN is approved. However, this does not prevent the running of another portion of the test unaffected by the change.

5 EXECUTION

5.1 OCCUPATIONAL SAFETY AND HEALTH

Individuals shall carry out their assigned work in a safe manner to protect themselves and others from undue hazards and to prevent damage to property and environment. Facility line managers shall assure the safety of activities

GSS $9 / 10 / 96$ 
within their areas to prevent injury, property damage, or interruption of operation. Performance of test activities shall always include safety and health aspects.

These tests involve working near energized equipment; all procedural requirements for working near energized equipment shall be followed.

\subsection{PERFORMANCE}

5.2.1 Conduct testing in accordance with ICF KH Procedure CON 3.5 (Performance and Recording of Acceptance Test Procedures).

5.2.2 Perform test following the steps and requirements of this procedure.

5.2.3 As each step in Sections 7,8 , and 9 are completed, the person completing the step shat initial and date in the space provided.

\section{EXCEPTIONS}

6.1 GENERAL

Exceptions to the required test results are sequentially numbered and recorded on individual exception forms $(\mathrm{KEH}-428)$. This enables case-by-case resolution and approval of each exception.

Errors/exceptions in the ATP itself shal1 NOT be processed as test exceptions (see Section 4 CHANGE CONTROL).

\section{$6.2 \quad$ RECORDING}
6.2 .1
Number each exception sequentialiy as it occurs and record it on an exception form.
6.2.2 Enter name and organization of the individual that identifies each exception.

6.2.3 Enter planned action to resolve each exception when such determination is made.

\subsection{RETEST/RESOLUTION}

Record the action taken to resolve each exception. Action taken may not be the same as planned action.

6.3.1 When action taken results in an acceptable retest, sign and date Retest Execution and Acceptance section of the exception form.

6.3.2 When action taken does not involve an acceptable retest, strike out the Retest Execution and Acceptance section of the exception form. 
The Test Director provides final approval and acceptance of exceptions by checking one of the following on exception form:

6.4.1 Retest Approved and Accepted: Applicable when Retest Execution and Acceptance section is completed.

6.4.2 Exception Accepted-As-Is: Requires detailed.explanation.

6.4.3 Other: Requires detailed explanation.

The Test Director signs and dates the exception form and obtains other approvals, if required.

\subsection{DISTRIBUTION}

A copy of the approved exception form is distributed to each participant. The signed original is attached to the ATP Master.

7 PREREQUISITES, EQUIPMENT/INSTRUMENTS, AND ABBREVIATIONS

7.1 PREREQUISITES

The following conditions shall exist at start of testing for that portion of the system being tested.

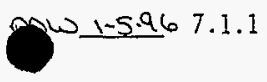

oow $1-5-967.1 .2$

$00621-5-967 \cdot 1 \cdot 3$

ous $21-5-967.1 .4$

$\operatorname{Ech} \frac{-184}{1-18.96}+1.5$

00215.967 .1 .6

Dow $21-5-967.1 .7$

$00 w 1.5-967.1 .8$

$10421-5.267 .1 .9$
Systems have been inspected for compliance with construction documents.

Reference documents (including this ATP) have been verified for correct revision number and outstanding ECNs.

A Prejob Safety Analysis has been prepared and a Prejob Safety Meeting has been conducted.

Test instruments have a valid calibration stamp attached. Test instrument identification numbers and calibration expiration dates have been recorded in Step 7.2 .

Power is-tagged out-upstram (primary side) 0 - the 13 - $k 4-480-4$ stpply transformer. Deleted per Ecro w.320-184

Power is available at the $13.8 \mathrm{kV}$ lines. Taps on the $13.8 \mathrm{kV}-480 \mathrm{~V}$ supply transformer have been set to provide $480 \vee$ within range of $+5 \%$ and $-0 \%$. Actual tap depends on the value of the supply voitage to the transformer primary.

Power Distribution Panel (C-POP-1) circuit breakers have been continuity tested.

Wiring for the entire system has been continuity tested, meggered, and hy-potted, as applicable.

ICF KH Utilities has released the supply transformer for use. 
sol $1-5.967 .1 .10$

oow $1-5.967 .1 .11$

$31-5.967 .1 .12$

Dow $21-5.967 .1 .13$

$0001-5-967.1 .14$

oow1-5.967.1.15
Grounding has been visually inspected and continuity tested.

Al1 circuit breakers on the PDP are open (OFF position).

A11 circuit breakers on the Transformer/Breakers Skid are open (OFF position).

All circuit breakers on the Transfer Switches/Breakers Skid are open (OFF position).

The disconnects on the $W-320$ support trailers are open.

A17. worker safety equipment required to perform test is readily available.

7.2 EQUTPHEMT/INSTRUMENTS

Supplied by Test Operator unless otherwise noted.

7.2.1 Volt-ohmmeters (VOM): $120 / 240$ to $277 / 480 \mathrm{~V}$

Instrument No. Or40 Expiration Date 5-10.96

7.2.2 Ammeters: $0-10$ amp (Low amperes anticipated since no load.)

Instrument No.950.45-02-035 Expiration Date - 4-28.96

7.2.3 Phase Rotation Meter

Instrument-No. Expiration Date

7.3 ABBREVIATIONS
A
A phase voltage or current
B
B phase voltage or current
C
$C$ phase voltage or current
CB Circuit Breaker
CT Current Transformer
ECN Engineering Change Notice
ERS Equipment Removal System
GND/G Ground or Ground Bus .
H $\quad 120 \mathrm{~V}$ Hot Leg
HPPT High Pressure Pump Trailer
IT Instrument Trailer
L1 First $120 \mathrm{~V}$ Hot Leg 
L2 Second $120 \mathrm{~V}$ Hot Leg

HCC Motor Control Center

PDP Power Distribution Panel

PT Potential Transformer

SBT Strong Back Trailer

SPT Single-phase Transformer

TS Transfer switch

VOM Volt-ohmmeter 
8 - EQUIPMENT REMOVAL SYSTEM - C-FARM ELECTRICAL TESTS

\subsection{PREPARATION}

1-18.968.1.1 Verify prerequisites of Step 7.1 have been met.

\section{2}

\section{CIRCUIT BREAKER SETTINGS}

The following steps will establish the settings for the Main Disconnect breaker and the MCC-N1 feeder breaker.

$\infty$

8.2 .1

opw 1.5 .968 .2 .2

oow $1.5-968.2 .3$

oow 1.5 .968 .2 .4

olow $1-5.968 .2 .5$

Verify that the Main Disconnect breaker has an 800 amp rating plug installed in the T36 Digitrip RMS 310 module. If an adjustable plug is installed, it should be set at 800 amp.

Yerify that the Main Disconnect breaker has the short delay pickup set at $8 \times I_{n}$ and that the time delay is set at $300 \mathrm{~ms}$.

Verify that the Main Disconnect breaker has ground fault settings at 200 amps (IX) and Inst (0 ms).

Verify that the MCC-NI feeder breaker has an 800 amp plug installed in the T33 Digitrip RMS 310 module. If an adjustable plug is installed, it should be set at $800 \mathrm{amp}$.

Yerify that the MCC-NI feeder breaker has the short time delay pickup set at $6 \times I_{n}$.

\section{3 \\ IQ DATA SETTINGS}

$1-5.968 .3 .1$

Remove plastic cover from the IQ data module.

Locate the voltage selection block to the left of center of the unit. Set jumpers for operation at -425 to $680 \%$. 460 to $575 \mathrm{~V}$. Ecro- W330.194

Locate the 2 field selectable OIP switches to the upper right corner of the module. The 2 DIP switches have 8 switches which may be positioned. Position these DIP switches as follows:

\begin{tabular}{|c|c|}
\hline SWITCH 1 & SHITCH 2 \\
\hline SW $1-O N$ & SW $1-O N$ \\
\hline SW 2 - OFF & SH $2-O N$ \\
\hline SW $3-O N$ & SW $3-O N$ \\
\hline SW 4 - OFF. & SW $4-O N$ \\
\hline SW $5-$ ON & SW 5 - UNUSED \\
\hline SW 6 - UNUSED & SW 6 - UNUSED \\
\hline SW 7 - UNUSED & SW 7 - UNUSED \\
\hline SW $8-$ ON & SW $8-O F F$ \\
\hline
\end{tabular}


Now 1.5.96 8.3.4 Reinstall the plastic cover.

CAUTION: Observe proper electrical safety precautions around energized equipment.

8.4

oow 1.5.968.4.1

Dow 1.18 .968 .4 .2

Dow 1-5.56. 8.4.3

Dow $1.5: 968.4 .4$

$00 \omega 1-5.968 .4 .5$

Dow $1-5-968.4 .6$

$00 w 1-18-968.4 .7$

Dow $1-18.968 .4 .8$

0001.5 .968 .4 .9

Dw $1-3-968.4 .10$

$0001-5.960 .4 .11$

oow $1-5.968 .4 .12$

$0001-5-968.4 .13$

$00 \times 21.5 .968 .4 .14$

Oow $21.5-968.4 .15$

$00001-5-968.4 .16$

o0usi-5.96 8.4.17

$00 \operatorname{col} 1-5-968.4 .18$
Connect the phase rotation meter at the output of the MCC-NI feeder breaker.

Yerify the 225 kVA Transformer C-T-1 is energized Added par Ecru-184 Close the Main Disconnect breaker (ON position).

Using the VOM, measure $V_{A B}$ across the secondary of the potentia? transformers. Record results in Data Sheet.

Using the VOM, measure $V_{B C}$ across the secondary of the potential transformers. Record results in Data Sheet.

Using the VOM, measure $V_{C A}$ across the secondary of the potential transformers. Record results in Data Sheet.

If any of the voltages in Steps 8.4.3, 8.4.4, and 8.4.5 are not within the range of 400 to $510-4$ stop the test and notify the Test Director. 120 to $127.5^{2} v$ Reuised per Ecro-184 Piace voltage transducer disconnect switch to Off, EcW. P04 Test the Main Disconnect braaker using the red test pushbutton on the Digitrip unit. If the circuit breaker does not trip, notify the Test Director.

Reset and close the Main Disconnect breaker (ON position).

Close the MCC-NI feeder breaker (ON position).

Test the MCC-NI feeder breaker using the red test pushbutton on the Digitrip unit. If the circuit breaker does not trip, notify the Test Director.

Reset and close the MCC-NI feeder breaker (ON position).

Using the phase rotation meter, verify that the phase rotation corresponds to the Hanford standard, clockwise rotation for $A, B, C$. If not, stop the test and notify the Test Director.

Open the MCC-NI feeder breaker (OFF position).

Connect the VOM to measure $V_{A B}$ on the load side of the MCC-NI feeder breaker.

Close the MCC-N1 feeder breaker (ON position).

Switch the IQ Data unit to record $V_{A B}$. Record the displayed value on the Data Sheet.

Record the value from the VOM on the Data Sheet. 
(x) 1.5 .968 .4 .19

$1-5.968 .4 .20$

oरे. $1-5.968 .4 .21$

Dow 1.5 .968 .4 .22

O0w 1.5966 .4 .23

Sos. $1-5.968 .4 .24$

Jbs 1.5 .968 .4 .25

Do_. $1-5.968 .4 .26$

$00101-5.968 .4 .27$

00.21 .5 .968 .4 .28

DQD. 8.5 .96 .29

$000_{1-5.96} 8.4 .30$

i) $1=5-968.4 .31$

ood 1.5 .968 .4 .32

Dow $\quad .45 .968 .4 .33$

$0061-5.968 .4 .34$

$001-5-968.4 .35$

Dow $1-5.968 .4 .36$

$00101-5.968 .4 .37$

pad $1-5.968 .4 .38$

$0001-5-968.4 .39$

$00,1-5.968 .4 .40$

$1-5.968 .4 .41$
Verify that the voltages in the preceding two steps are in the range of 480 to $510 \mathrm{~V}$. If not, stop the test and notify the Test Director.

Open the MCC-N1 feeder breaker (OFF position).

Connect the VOM to measure $V_{B C}$ on the load side of the MCC-NI feeder breaker.

CTose the MCC-NI feeder breaker (ON position).

Switch the IQ Data unit to record $V_{8 C}$. Record the displayed value on the Data Sheet.

Record the value from the VOM on the Data Sheet.

Verify that the voltages measured in the preceding 2 steps are in the range of 480 to $510 \mathrm{~V}$. If not, stop the test and notify the Test

Director.

Open the MCC-N1 feeder breaker (OFF position).

Connect the VOM to measure $V_{C A}$ on the load side of the MCC-N1 feeder breaker.

Close the MCC-N1 feeder breaker (ON position).

Switch the IQ data unit to record $V_{C A}$. Record the displayed value on the Data Sheet.

Record the value from the VOM on the Data Sheet.

Verify that the voltages measured in the preceding 2 steps are in the range of 480 to $510 \mathrm{~V}$. If not, stop the test and notify the Test

Director.

Open the MCC-NI feeder breaker (OFF position).

Connect the VOM to measure $V_{A M}$ on the load side of the MCC-NI feeder breaker.

Close the MCC-N1 feeder breaker (ON position).

Switch the IQ Data unit to record $V_{A K}$. Record the displayed value on the Data Sheet.

Record the value from the VOM on the Data Sheet:

Close the MCC-Nl feeder breaker (OFF position).

Connect the VOM to measure $V_{B N}$ on the load side of the MCC-NI feeder breaker.

Close the MCC-N1 feeder breaker (ON position).

Switch the IQ data unit to record $V_{B N}$. Record the displayed value on the Data Sheet.

Record the value from the VOM on the Data Sheet. 
$\cos 1.5-968: 4.42$

Dow $1-5-968.4 .43$.

OOW $1=5.968 .4 .44$

Dow 21.5 .968 .4 .45

$0001-5.968 .4 .46$

op $1-5.968 .4 .47$

Dow 1.5 .968 .4 .48
Open the MCC-N1 feeder breaker (OFF position).

Connect the VOM to measure $V_{c x}$ on the load side of the MCC-N1 feeder breaker.

Close the MCC-N1 feeder breaker (ON position).

Switch the IQ Data unit to record $y_{c x}$. Record the displayed value on the Data Sheet.

Record the value from the VOM on the Data Sheet.

Verify that the voltages measured in Steps $8.4 .36,8.4 .41$, and 8.4 .46 are in the range of. 277 to $295 \mathrm{~V}$. If not, stop the test and notify the Test Director.

Open the MCC-N1 feeder breaker (OFF position). Disconnect the VOM.
8.5

NOTE:

$\operatorname{Dod} 1-5-968.5 .1$

$\operatorname{Dos} 1.5968 .5 .2$

and $1-5.968 .5 .3$

$=5.968 .5 .4$

$00.5-968.5 .5$

$0061.5-968.5 .6$

$001-5968.5 .7$

$00(.21 .5 \cdot 968.5 .8$

DDW 1.5 .968 .5 .9

$00 \omega) 1-5-968: 5 \cdot 10$
Since there are no loads applied to the PDP, values of current in the following steps are expected to be very low.

Place the clamp-on ammeter to measure the current flowing in the A phase to the Main Disconnect breaker.

Record the A phase current on the Data Sheet.

Switch the IQ Data unit to record $I_{A}$. Record the displayed value on the Data Sheet.

Place the clamp-on ammeter to measure the current flowing in the $B$ phase.to the Main Disconnect breaker.

Record the $B$ phase current on the Data Sheet.

Switch the IQ data unit to record $I_{B}$. Record the displayed value on the Data Sheet.

Place the clamp-on ammeter to measure the current flowing in the $C$ phase to the Main Disconnect breaker.

Record the $C$ phase current on the Data Sheet.

Switch the IQ Data unit to record $I_{c}$. Record the displayed value on the Data Sheet.

The phase currents measured by the IQ Data unit should be approximately the same as the measurement of the same current by the clamp-on ammeter. For each phase, compare the 2 measurements. If they differ by more than 10\%, notify the Test Director. (Since there is no load on the PDP, the currents should be close to zero.) 
Oow. 1.5 .968 .6 .1

$0061-5.968 .6 .2$

pow $1-5.968 .6 .3$

Oox $>1.5 .968 .6 .4$

$0001-5-968.6 .5$
Close the Transformer/Breakers Skid feeder breaker located at the C-POP-1 (ON position).

Close the primary circuit breaker (SPT-PRIMARY-CB) that supplies transformer SPT.

Using the VOM, measure the secondary voltage across the hot legs; LI and L2, of the transformer. Record value on the Data Sheet. If this value is less than $210 \mathrm{~V}$ or greater than $260 \mathrm{~V}$, stop the test and notify the Test Director.

Using the VOM, measure the voltage from one of the hot legs to the transformer neutra?. Record the value on the Data Sheet. If this value is less than $110 \mathrm{~V}$ or greater than $135 \mathrm{~V}$, stop the test and notify the Test Director.

Using the VOM, measure the voltage from the other hot leg to the transformer neutral. Record the value on the Data Sheet. If this yalue is less than $110 \mathrm{~V}$ or greater than $135 \mathrm{~V}$, stop the test and notify the Test Director.

\subsection{CONSTRUCTION CONEX TRALLER}

Q) 1.5968 .7 .1

Cow $1-5.968 .7 .2$

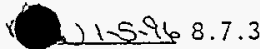

$00.21-5-968.7 .4$
Close feeder breaker CC-FB on the Transformer/Breakers Skid (ON position).

Using the YOM, measure the voltage from hot (L1) to neutral on the Toad side of the feeder breaker. Record the value on the Data Sheet.

Using the voM, measure the voltage from the other hot leg (L2) to neutral on the load side of the feeder breaker. Record the value on the Data Sheet.

Verify both voltage measurements are in the range of 110 to $135 \mathrm{~V}$; if not, stop the test and notify the Test Director.
8.8

oove $1-5.968 .8 .1$

Dos $1-5-968.8 .2$

$1-5-968.8 .3$

$1-5-968.8 .4$
Close feeder breaker OFF-FB on the Transformer/Breakers Skid (ON position).

Using the YOM, measure the voltage from hot (LI) to neutral on the load side of the feeder breaker. Record the value on the Data Sheet.

Using the YOM, measure the voltage from the other hot leg (L2) to neutral on the load side of the feeder breaker. Record the value on the Data Sheet.

Verify both voltage measurements are in the range of 110 to $135 \mathrm{~V}$; if not, stop the test and notify the Test Director.

\subsection{WRAM/CHANGE TRAILER}

Daw $1-5-968.9 .1$

Close feeder breaker WE-FB on the Transformer/Breakers Skid

(ON position). 
$5-968.9 .2$

$-5.968 .9 .3$

$0021-5.968 .9 .4$

Using the VOM, measure the voltage from hot (L1) to neutral on the load side of the feeder breaker. Record the value on the Data Sheet.

Using the VOM, measure the voltage from the other hot leg (L2) to neutral on the load side. of the feeder breaker. Record the value on the Data Sheet.

Verify both voitage measurements are in the range of 110 to $135 \mathrm{~V}$; if not, stop the test and notify the Test Director.

8.10

Ox. 1.5 .968 .10 .1

$00.21-5.968 .10 .2$

$00.51-5.968 .10 .3$

$000 \div 5.968 .10 .4$

$001.5-968.10 .5$

$0(x) 1-5.968 .10 .6$

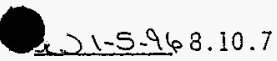

(0). 1-5.968.10.8

$0 Q \times 21-5.968 .10 .9$

$0001-5.968 .10 .10$

$O(x, 2)-5.968 .10 .11$

$00 \times 01-5968.10 .12$

$O Q D 1=5-968.10 .13$

$0021-5.968 .10 .14$

DQ6. 1.5 .968 .10 .15

$00.01-5.968 .10 .16$
Open door of transfer switch HPPT-TS. Connect the VOH to read $V_{A B}$ at the load terminals of transfer switch HPPT-TS. Also, connect the phase rotation meter at the same load terminals.

Close the HPPT-FB feeder breaker at the PDP (ON position).

Defeat the interlock in transfer switch HPPT-TS, and shift transfer switch HPPT-TS to the NORMAL position.

Record the value from the Vom on the Data Sheet. Verify that the phase rotation corresponds to the Hanford standard, clockwise rotation for $A, B, C$. If not, stop the test and notify the Tesi Director.

Open the HPPT-FB feeder breaker at the POP (OFF position).

Connect the VOM to read $V_{A C}$ at the load terminals of transfer switch HPPT-TS. Disconnect the phase rotation meter.

Close the HPPT-FB feeder breaker at the POP (ON position).

Record the value from the yom on the Data Sheet.

Verify that the voltages measured in Steps 8.10 .4 and 8.10 .8 are in the range of 480 to $510 \mathrm{~V}$. If not, stop the test and notify the Test Director.

Open the HPPT-FB feeder breaker at the PDP (OFF position).

Disconnect the VOM from transfer switch HPPT-TS and close the door.

Shift transfer switch HPPT-TS to the OFF position.

Open door of transfer switch IT-TS. Connect the YOM to read $V_{A B}$ at the load terminals of transfer switch IT-TS. Also, connect the phase rotation meter at the same load terminals.

Close the IT-FB feeder breaker at the PDP (ON position).

Defeat the interlock in transfer switch IT-TS and shift transfer switch IT-TS to the NORMAL position.

Record the value from the VOM on the Data Sheet. Verify that the phase rotation corresponds to the Hanford standard, clockwise rotation for $A, B, C$. If not, stop the test and notify the Test Director. 
(20. 1 -5968.10.17 001.5 .968 .10 .18

$00201.5-968.10 .19$ $0 Q 21.5 .968 .10 .20$ $00 \underline{1.5 .96} 8.10 .21$

$\cos 1.5-968.10 .22$ OQ $1-5-968.10 .23$ ox 1.5 .968 .10 .24 oct 1.5 .968 .10 .25

oo. $1-5-968.10 .26$ Dow $1.5-968.10 .27$ OQd $1-5.968 .10 .28$ 0

$00031-5-968.10 .29$ og) 1.5.968.10.30 00.01 .5 .968 .10 .31 Dow) 1.5 .968 .10 .32 $00 \geq 1-5.96 \quad 8.10 .33$

oow 1.5 .968 .10 .34 Dow $1-5.968 .10 .35$ obiw $1-5-968.10 .36$
Open the IT-FB feeder breaker at the PDP (OFF position).

Connect the YOM to read $V_{A C}$ at the load terminals of transfer switch IT-TS. Disconnect the phase rotation meter.

Close the IT-FB feeder breaker at the POP (ON position).

Record the value from the VOM on the Data Sheet.

Verify that the yoltages measured in Steps 8.10 .16 and 8.10 .20 are in the range of 480 to $510 \mathrm{~V}$. If not, stop the test and notify the Test Director.

Open the IT-FB feeder breaker at the PDP (OFF position).

Disconnect the YOM from transfer switch IT-TS and close the door.

Shift transfer switch IT-TS to the OFF position

Open door of transfer switch SBT-TS. Connect the VOM to read $V_{A B}$ at the load terminals of transfer switch SBT-TS. Also, connect the phase rotation meter at the same load terminais.

Close the SBT-FB feeder breaker at the POP-(ON position).

Defeat the interlock in transfer switch SBT-TS and shift transfer switch SBT-TS to the NORMAL position.

Record the value from the YOM on the Data Sheet. Verify that the phase rotation corresponds to the Hanford standard, clockwise rotation for $A, B, C$. If not, stop the test and notify the Test Director.

Open the SBT-FB feeder breaker at the PDP (OFF position).

Connect the VOM to read $V_{A C}$ at the load terminals of transfer switch SBT-TS. Disconnect the phase rotation meter.

Close the SBT-FB feeder breaker at the POP (ON position).

Record the value from the VOM on the Data Sneet.

Verify that the voltages measured in Steps 8.10 .28 and 8.10 .32 are in the range of 480 to $510 \mathrm{~V}$. If not, stop the test and notify the Test Director.

Open the SBT-FB feeder breaker at the PDP (OFF position).

Disconnect the VOM from transfer switch SBT-TS and close the door.

Shift transfer switch SBT-TS to the OFF position. 
9 - TEST COMPLETION FINAL EQUIPMENT LINEUP

Upon completion of the testing steps, the positions of circuit breakers and disconnect switches used in this test should be as shown in the following table. If any of the devices are not in the required position, notify the Test Director. The Test Director will determine the appropriate action.

\begin{tabular}{|c|c|c|c|}
\hline \multicolumn{4}{|c|}{ TEST COMPLETION FINAL EQUIPHENT, LINEUP } \\
\hline LOCATION & PERFORM/VERIFY & INITIAL & DATE \\
\hline $\begin{array}{l}\text { XFER SW/BKRS } \\
\text { SKid }\end{array}$ & Breaker HPPT-FB: OFF & Dow & $1-5.96$ \\
\hline $\begin{array}{l}\text { XFER SW/BKRS } \\
\text { SKid }\end{array}$ & Breaker IT-FB: OFF. & Dow & $1-3.96$ \\
\hline $\begin{array}{l}\text { XFER SW/BKRS } \\
\text { Skid }\end{array}$ & Breaker SBT-FB: OFF & oow & $1-5.96$ \\
\hline $\begin{array}{l}\text { XFER SH/BKRS } \\
\text { SKid }\end{array}$ & Transfer switch HPPT-TS: OFF & $00 \omega$ & $1-5.96$ \\
\hline $\begin{array}{l}\text { XFER SW/BKRS } \\
\text { SKId }\end{array}$ & Transfer switch IT-TS: OFF & Dow & $1-5.96$ \\
\hline $\begin{array}{l}\text { XFER SH/BKRS } \\
\text { SKid }\end{array}$ & Transfer switch SBT-TS: OFF & Dow & $1-5.96$ \\
\hline $\begin{array}{l}\text { XFMR } \\
\text { XFERH/BKRS } \\
\text { SKid EcW-184 }\end{array}$ & Breaker SPT-PRIMARY: ON & . Dow & $1-18-96$ \\
\hline $\begin{array}{l}\text { XFMR/BKRS } \\
\text { SKid }\end{array}$ & Breaker CC-FB: ON & oow & $1-5-96$ \\
\hline $\begin{array}{l}\text { XFMR/BKRS } \\
\text { Skid }\end{array}$ & Breaker OFF-FB: ON & row & $1-5.96$ \\
\hline $\begin{array}{l}\text { XFMR/BKRS } \\
\text { SKid }\end{array}$ & Breaker WE-FB: $O N$ & Dow & $1-5-96$ \\
\hline $\begin{array}{l}\text { XFMR/BKRS } \\
\text { SKid }\end{array}$ & GEN AUX breaker: OFF & oow & $1-5-96$ \\
\hline POP & Breaker MCC-NI: OFF & oow & $1-5.96$ \\
\hline POP. & Breaker IT-FB: OFF & Dow & $1-5-96$ \\
\hline PDP & Breaker HPPT-FB: OFF & oow & $1-5-96$ \\
\hline POP & Breaker SBT-FB: OFF & $00 \omega$ & $1-5-96$ \\
\hline PDP & Breaker TRANSFORMER/BREAKERS SKID: ON & oon & $1-5.96$ \\
\hline PDP & A]1 (4) SDare breakers: OFF & Dow & $1-5.96$ \\
\hline PDP & Main Disconnect Breaker: ON & OON & $1-5-96$ \\
\hline
\end{tabular}

QSS9/10/96 


\begin{tabular}{|c|c|c|c|c|}
\hline & & \multirow[b]{2}{*}{ MEASUREHENT } & \multirow[b]{2}{*}{ INITIAL } & \multirow[b]{2}{*}{ DATE } \\
\hline STEP & - PERFORH/VERIFY & & & \\
\hline 8.4 .3 & Measurement of PT voltage $V_{A B}=$ & 124.5 volts & 000 & $1-5.96$ \\
\hline 8.4 .4 & Measurement of PT voltage $V_{3 c}=$ & 125.6 volts & Dow & $1-5.96$ \\
\hline 8.4 .5 & Measurement of PT voltage $V_{C A}=$ & 125.6 volts & Dow & $1-5.96$ \\
\hline 8.4 .17 & IQ DATA $V_{A B}=$ & 496, volts & OQn & $1-9.96$ \\
\hline 8.4 .18 & VOM $V_{A B}=$ & 495. volts & OOW & $1-5-26$ \\
\hline 8.4 .23 & IQ DATA $V_{8 C}=$ & 500 volts & Don & 1.5 .96 \\
\hline 8.4 .24 & VOM $V_{3 C}=$ & 501. volts & $00 \omega$ & 1.5 .96 \\
\hline 8.4 .29 & IQ DATA $V_{C A}=$ & soo, volts & OQD & $1-5-26$ \\
\hline 8.4 .30 & YOM $V_{C A}=$ & sol. volts & Non & $1-3.96$ \\
\hline 8.4 .35 & IQ DATA $V_{\text {AII }}=$ & 287 . volts & OQNes & $1-5-96$ \\
\hline 8.4 .36 & VOM $V_{A K}=$ & 284.6 volts & Now & 1.5 .96 \\
\hline 8.4 .40 & IQ DATA $\mathrm{DAll}_{\mathrm{B}}=$ & 288. vo.7ts & $\Delta x_{2}$ & $1-5-96$ \\
\hline 8.4 .41 & VOM $V_{S N}=$ & 285 . volts & (x) & $1-5.96$ \\
\hline 8.4 .45 & IQ OATA $V_{C Y}=$ & 291. volts & cow? & $1-5.96$ \\
\hline 8.4 .46 & VOM $V_{C M}=$ & 288.7 volts & 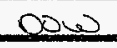 & 1.5 .96 \\
\hline 8.5 .2 & Ammeter $A$ ph $=$ & O amps & OD & $1-5.96$ \\
\hline 8.5 .3 & IQ DATA A ph $=$ & Q. amps & oow & $1-5-96$ \\
\hline 8.5 .5 & Anmeter $B$ ph $=$ & O amps & oow & 1.5 .96 \\
\hline 8.5 .6 & IQ DATA B ph $=$ & 0 amps! & DOW & 1.5 .96 \\
\hline 8.5 .8 & Ammeter $\mathrm{C}$ ph $=$ & amps & $00(0)$ & $1-5.96$ \\
\hline 8.5 .9 & IQ DATA C ph $=$ & 0 amps| & $\infty 0, \infty$ & $1-5.96$ \\
\hline 8.6 .23 & SPT full secondary voltage $=$ & 250.4 yolts & $\infty D_{2}$ & 1.5 .96 \\
\hline 8.6 .264 & SPT LI voltage $=$ & 125,2 yolts & 002 & $1-5.96$ \\
\hline 8.6 .45 & SPT L2 voltage $=$ & 125. yolts & 0020 & 1.596 \\
\hline 8.7 .2 & $C C-F B \quad Y_{L 1} \Rightarrow$ & 124.9 volts & 00.0 & $1-5-96$ \\
\hline 8.7 .3 & $C C-F B V_{12}=$ & 124.9 volts & 000 & $1-5.96$ \\
\hline 8.8 .2 & $O F F-F B \quad V_{L 1}=$ & 124.8 volts & Dow & $1-5-96$ \\
\hline 8.8 .3 & $O F F-F B V_{t 2}=$ & 124.8 volts & Dow & $1-5.96$ \\
\hline 8.9 .2 & $W E-F B \quad V_{4}=$ & 124.9 volts & Oas & $1.5-96$ \\
\hline 8.9 .3 & $\mathrm{WE}-\mathrm{FB} V_{\mathrm{L2}}=$ & 124,9 volts & DOW & $1-5-96$ \\
\hline 8.10 .4 & HPPT-TS VOM $V_{A B}=$ & 496 , volts & oow & 1.5 .96 \\
\hline 8.10 .8 & HPPT-TS VOM V $A C=$ & 501 volts & 000 & 1.3 .96 \\
\hline 8.10 .16 & IT-TS VOM $V_{A B}=$ & 496 , volts & Dow & $i-5.96$ \\
\hline 8.10 .20 & $I T-T S$ VOM $V_{A C}=$ & 501. volts & OOW & $1-5-96$ \\
\hline 8.10 .28 & SBT-TS VOM $V_{A 8}=$ & 496. volts & $00 \omega$ & $1-5.96$ \\
\hline 8.10 .32 & SBT-TS VOM $V_{A C}=$ & 50 volts & 000 & $1-5-96$ \\
\hline
\end{tabular}

8.7 .2

8.7 .3 


\begin{tabular}{|c|c|c|c|}
\hline \multicolumn{3}{|c|}{ ENGINEERING CHANGE NOTICE } & \\
\hline \multirow{3}{*}{$\begin{array}{l}\text { 2. ECH Category } \\
\text { (mark one) } \\
\text { Supplementat } \\
\text { Direct Revision } \\
\text { Change ECN } \\
\text { Temporary } \\
\text { Standby } \\
\text { Supersedure } \\
\text { Cancel/Void }\end{array}$} & $\begin{array}{l}\text { 3. Originator's Mame, Organization, MSIH, } \\
\text { and Yelephone No. } \\
\text { DA MORASCH, ICF KH, S5-50, } \\
376-4102\end{array}$ & $\begin{array}{l}\text { 3a. USQ Required? } \\
{[] \text { Yes }[X] \text { No }}\end{array}$ & 4. Date \\
\hline & $\begin{array}{l}\text { 5. Project Title/No./Work order No. } \\
\text { EQUIPMENT REMOVAL SYSTEM / W320 } \\
\qquad / \text { P43G21 }\end{array}$ & $\begin{array}{l}\text { 6. Bldg./Sys./Fac. No. } \\
\text { C-PDP-1 / 200E }\end{array}$ & $\begin{array}{l}\text { 7. Approval Designator } \\
\mathrm{SO} / \mathrm{SC} 3\end{array}$ \\
\hline & $\begin{array}{l}\text { 8. Document Numbers Changed by this ECH } \\
\text { (includes sheet no. and rev.) Sqa } 1 / 31 / 96 \\
\text { WHC-SD }-320-A T P-004 \text {, ReV. } 0\end{array}$ & $\begin{array}{c}\text { 9. Related ECN No(s). } \\
\text { N/A }\end{array}$ & $\begin{array}{r}\text { 10. Related PO No. } \\
\text { N/A }\end{array}$ \\
\hline $\begin{array}{l}\text { 11a. Modification Work } \\
\text { [] Yes (fill out Blk. } \\
\text { 11b) } \\
{[X] \text { No (NA Blks. 11b, }} \\
11 c, 11 d)\end{array}$ & \begin{tabular}{|l|l|} 
11b. Work Package & 11e. Modification Work \\
Ho. & \\
N/A & \\
\end{tabular} & \begin{tabular}{l|l} 
:omplete & $\begin{array}{l}11 d . \\
\text { tion }\end{array}$ \\
\end{tabular} & $\begin{array}{l}\text { 11d. Restored to Originat Condi- } \\
\text { tion (Temp. or Standby ECH only) }\end{array}$ \\
\hline \multicolumn{4}{|c|}{ 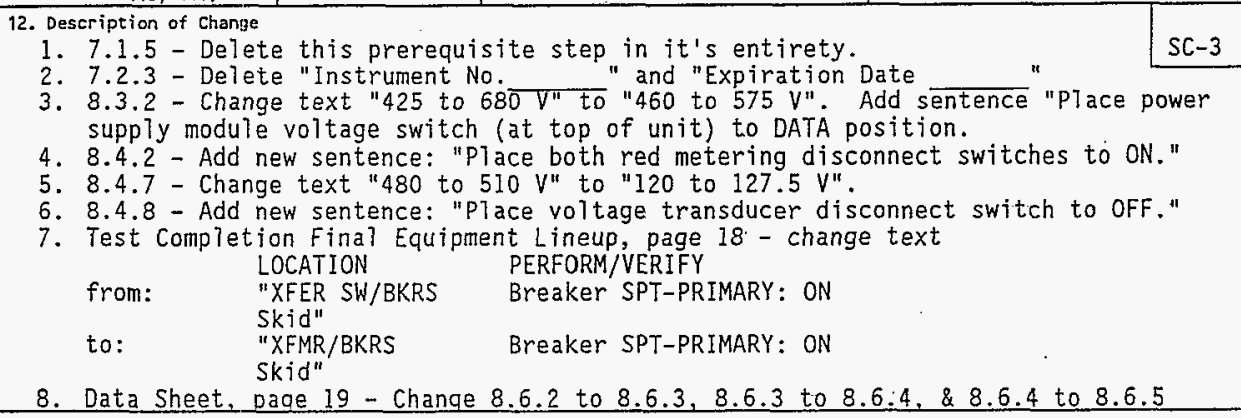 } \\
\hline \multicolumn{4}{|c|}{$\begin{array}{l}\text { 138. Justification (mark one) } \\
\text { Criteria Change [] Design Improvement [] }\end{array}$} \\
\hline
\end{tabular}

13b. Justification Detaits

Change the ATP to reflect As-Found field conditions.

\begin{tabular}{|c|c|}
\hline $\begin{array}{l}\text { 14. Distribution (inclucle name, MSI } \\
\text { ICF KH DISTRIBUTION }\end{array}$ & $\begin{array}{l}\text { ind no. of copies) } \\
\text { WHC DISTRIBUTION }\end{array}$ \\
\hline Const DoC Cnt1 S2-53 & $\begin{array}{l}\text { D. E. Bowers } \\
\text { J. J. Huston } \\
\text { T. H. May (COG) }\end{array}$ \\
\hline
\end{tabular}

A-7900-013-2 (11/94) GEF095

$$
\begin{gathered}
-20 \text { - WHC-SD-W320-ATR - } 004 \\
\text { GDS. } 0 \\
\text { 9110196 }
\end{gathered}
$$


